\title{
Pathogen group-specific risk factors for intramammary infection in treated and untreated dairy heifers participating in a prepartum antimicrobial treatment trial
}

\author{
P. Passchyn, ${ }^{*} \dagger^{1}$ S. Piepers, $\dagger$ and S. De Vliegher $†$ \\ *Independent Dairy Consultant, Milk@vice, Torhout 8820, Belgium \\ †M-team and Mastitis and Milk Quality Research Unit, Department of Reproduction, Obstetrics, and Herd Health, Faculty of Veterinary Medicine, \\ Ghent University, Merelbeke 9820, Belgium
}

\begin{abstract}
Heifer mastitis is a well-known problem, with several pathogens being involved. Several generic risk factors associated with the likelihood of intramammary infections (IMI) in fresh dairy heifers have been identified before. Yet, a need exists to identify pathogen groupspecific factors, as the effect of (groups of) pathogens on udder health and milk yield is different. The aim of the present study was to identify pathogen groupspecific risk factors for IMI in heifers participating in a prepartum antimicrobial treatment trial, allowing us to test the hypothesis that different factors are of importance between treated and untreated control heifers as well. Data from a clinical trial in which end-term heifers were treated systemically (over 3 consecutive days) $2 \mathrm{wk}$ before calving with penethamate hydriodide $(\mathrm{n}=76)$ or remained untreated $(\mathrm{n}=73)$, were available. Several potential risk factors at the herd, heifer, and quarter level were recorded in the first $3 \mathrm{~d}$ in milk. Quarters from untreated heifers supplemented with $\geq 4$ $\mathrm{mg}$ of selenium/d prepartum were significantly less likely to be infected with coagulase-negative staphylococci (CNS), whereas quarters were more likely to be infected with CNS when assistance during calving was needed. Udder edema before calving significantly decreased the odds of IMI with major pathogens. In treated heifers, no factors were detected that were associated with the likelihood of CNS IMI, whereas quarters from heifers were significantly more likely to be infected with major pathogens when they were housed in the calving pen more than $1 \mathrm{~d}$ and when they had been in contact with the lactating cows before calving. The risk factors for IMI that were identified in treated heifers were different than those in untreated heifers, independent of the pathogen group that was considered. It looks as if
\end{abstract}

Received March 9, 2014.

Accepted June 2, 2014.

${ }^{1}$ Corresponding author: pieter.passchyn@telenet.be prepartum treatment not only changed the likelihood of infection, but also the factors that were associated with infection. However, except for treated heifers with an IMI with major pathogens, only a small proportion of the variation could be explained in the final models. Therefore, factors other than those that were studied could explain the likelihood of infection.

Key words: heifer mastitis, prepartum antimicrobial treatment, risk factor, intramammary infection, pathogen group specific

\section{INTRODUCTION}

A high proportion of dairy heifers freshen with IMI, causing either clinical or subclinical mastitis (De Vliegher et al., 2012). Several pathogens are involved, with CNS being the most prevalent in most studies (Fox, 2009). Intramammary infections caused by major pathogens in early-lactation heifers are associated with elevated SCC in early lactation and result in milk production losses, udder health problems, and premature removal during the entire first lactation (De Vliegher et al., 2004, 2005a,b; Piepers et al., 2009, 2010), stressing the need for effective control measures. In contrast, CNS IMI in early-lactation heifers have a less pronounced effect on the heifers' future performance, making the need for prevention of IMI with CNS, at least in early-lactation heifers, not a priority, or even unwanted, as heifers with CNS IMI at calving produce more and have a lower incidence of clinical mastitis (CM) during their first lactation compared with noninfected heifers (Piepers et al., 2010, 2013; Pearson et al., 2013).

Several factors increasing the odds of IMI in fresh dairy heifers have been identified (e.g., McDougall et al., 2009). A 10-point program specifically focusing on the prevention and control of heifer mastitis was proposed (De Vliegher et al., 2012), but did not discriminate between mastitis pathogen types. Still, studying pathogen group-specific risk factors for IMI in early-lactation heifers allows for the development of pathogen-specific prevention and control programs. 
Farmers are often more eager to treat animals, even when this includes off-label use of antimicrobials, than to improve their herd management (McDougall et al., 2009). However, in the light of prudent drug use, and even though prepartum treatment of heifers with antimicrobials is probably the easiest way to reduce the prevalence of IMI at calving in the short term (Nickerson, 2009), preventing herd health problems, such as heifer mastitis, via nonantibiotic strategies is preferable over adopting blanket treatment protocols to reduce the risk of antibiotic residues in foodstuff (e.g., milk) and the development of antimicrobial resistance in pathogens and commensals. This needs to be stressed, as the long-term effects of prepartum antimicrobial treatment on farms suffering from heifer mastitis still remain undecided (Borm et al., 2006; Sampimon et al., 2009; Passchyn et al., 2013). Logic suggests that temporary use of antimicrobials in the control of a severe heifer mastitis problem can only be applied under strict conditions and when the etiology has been identified through culturing of milk samples, and should go along with the implementation of pathogen group-specific preventive measures at the same time to further reduce the risk for new IMI (De Vliegher et al., 2012). Still, even when antimicrobial treatment is applied in the weeks before calving, not all IMI will be cured or prevented and it is currently not known which risk factors are associated with IMI in fresh heifers treated before calving with antimicrobials. We hypothesized that risk factors for treated heifers would be different from the ones for untreated heifers.

\section{MATERIALS AND METHODS}

\section{Herds and Animals}

A clinical trial was conducted between September 2008 and June 2010 and included 229 heifers from 10 commercial, well-managed dairy herds, located in a radius of $20 \mathrm{~km}$ around the city of Torhout (province of West Flanders, Belgium). The trial was designed to assess both the short- and long-term effects of a systemic prepartum therapy with penethamate hydriodide on udder health and milk production (Passchyn et al., 2013).

Information on herd size, bulk milk SCC, heifer mastitis problems, and housing as well as the study design have been reported before (Passchyn et al., 2013). In short, before the actual trial was conducted, herds were first monitored by sampling the first 8 heifers per herd that calved ( 80 heifers in total). After the eighth heifer had calved, monitoring of a herd ended and the actual clinical trial, comprising approximately an additional 16 heifers, of which half were treated before calving
Table 1. Descriptive statistics of the number of herds, heifers, and quarters included in the different analyses

\begin{tabular}{lcccc}
\hline Data set & $\begin{array}{c}\text { Total } \\
\text { number }\end{array}$ & Average $^{1}$ & Median & Range \\
\hline Untreated heifers & & & & \\
$\quad$ Herd & 10 & - & - & - \\
$\quad$ Heifer & 73 & 7 & 8 & $6-8$ \\
$\quad$ Quarter & 292 & 29 & 32 & $24-32$ \\
Treated heifers & 10 & - & - & \\
$\quad$ Herd & 76 & 8 & 8 & $6-8$ \\
$\quad$ Heifer & 304 & 30 & 32 & $24-32$ \\
$\quad$ Quarter & & \\
\hline
\end{tabular}

${ }^{1}$ Average number of heifers and quarters per herd.

and half served as untreated controls, started for this herd (Table 1). Heifers were alternately assigned by the first author based on their expected calving date; every other heifer that was expected to calve was treated with penethamate.

Composite milk samples were taken between 0 and 3 DIM for SCC measurement when no visual signs of CM were observed. Also, quarter milk samples were taken between 0 and 3 DIM for bacteriological culture both from quarters with and without signs of CM.

\section{Sample Collection and Laboratory Analyses}

Samples. All heifers were sampled by the first author once between 0 to 3 DIM (further referred to as early lactation) for bacteriological culture $(5 \mathrm{~mL}$; duplicate quarter milk samples), were checked for signs of CM, and sampled for determination of milk SCC if no signs were present $(30 \mathrm{~mL}$; samples of different quarters were combined into a composite sample using equal volumes). All milk samples were collected after disinfection of the teats and after the first streams of milk were discarded. Milk samples were immediately stored at $4^{\circ} \mathrm{C}$ and then transported under cooled conditions to the laboratory (Milk Control Centre Flanders, Lier, Belgium).

Bacteriological Culture. Bacteriological culture was done as previously described (Piepers et al., 2007). Briefly, $0.01 \mathrm{~mL}$ of milk was plated on a blood-esculin agar (Oxoid NV, Erembodegem, Belgium; 1 plate per cow) and on MacConkey agar (Oxoid NV; 1 plate per cow). All plates were incubated aerobically for $36 \pm 12$ h at $37 \pm 1^{\circ} \mathrm{C}$. A quarter was considered culture-positive when growth of $\geq 1$ colony was detected. Samples yielding 3 or more different bacterial species were considered to be contaminated. Bacteria were identified by colony morphology and Gram staining. For gram-positive cocci, catalase tests were used to differentiate between catalase-positive staphylococci and catalase-negative cocci. Colony morphology, hemolysis patterns, and 
DNase testing were used to distinguish Staphylococcus aureus from CNS. Streptococci were subdivided into esculin-positive streptococci (Streptococcus uberis) and esculin-negative streptococci (Streptococcus agalactiae and Streptococcus dysgalactiae). Differentiation between Strep. uberis and other streptococci was done using bile esculin agar and $6.5 \% \mathrm{NaCl}$. The Christie, Atkins, Munch-Petersen (CAMP) test was used to differentiate Strep. agalactiae from Strep. dysgalactiae. Coliforms, including Escherichia coli, Klebsiella spp., and Enterobacter spp., were differentiated from each other and from other gram-negative bacteria based on the appearance on MacConkey agar, $\mathrm{KOH}$ testing, triple sugar iron reactions, indole production, and motility. Staphylococcus aureus, esculin-positive streptococci, Strep. agalactiae, Strep. dysgalactiae, and coliforms were considered as major pathogens. Coagulase-negative staphylococci and Corynebacterium bovis were considered as minor pathogens.

Penicillin Resistance. All staphylococci were tested by the E-test method (AB Biodisk, Solna, Sweden), a stable-gradient agar diffusion technique that produces quantitative MIC results over a $15 \log _{2}$ dilution range (Brown and Brown, 1991). Isolates were defined as susceptible to penicillin $\mathrm{G}$ when the MIC was $\leq 0.125$ $\mathrm{mg} / \mathrm{L}$ and as resistant to penicillin $\mathrm{G}$ when the MIC was $>0.125 \mathrm{mg} / \mathrm{L}$ (EUCAST, 2011).

$S C \boldsymbol{C}$. Milk SCC was quantified by electronic counting using a Fossomatic 5000 somatic cell counter (Foss Electric A/S, Hillerød, Denmark) at the Milk Control Centre Flanders.

\section{Data Collection}

Herd-Level Risk Factors. Binomial herd-level variables were constructed per herd using the data gathered from the monitoring heifers $(\mathrm{n}=80)$ before the start of the actual clinical trial and were used as potential herd-level risk factors for IMI (Table 2).

Heifer-Level Risk Factors. Several potential heifer-level risk factors were recorded at the moment of sampling (0-3 DIM; Table 2). Hygiene scores ranging from 1 (clean) to 5 (dirty) were assigned for 4 body areas: tail head, thigh, udder, and hind limbs (Hughes, 2001). As both udder hygiene score and leg hygiene scores are positively associated with IMI in lactating cows and a clear relationship exists between both hygiene scores (Schreiner and Ruegg, 2003), it was decided to combine them, rather than to evaluate them separately. Heifers with an average cleanliness score $\leq 2.0$ (median value of all heifers) were considered as clean and heifers with a cleanliness score $>2.0$ were considered as unclean. Information on fly control on pasture and the deworming program for yearling heifers (yes/no) was obtained through a face-to-face interview. The applied fly control strategy was considered to be effective if heifers had been provided with 2 Flectron ear tags (Zoetis Inc., Florham Park, NJ) just before entering the pasture or if during pasture season a heifer was treated with a pour-on solution registered for fly control in dairy cattle strictly in accordance with the manufacturer's instructions. Body condition was scored approximately $2 \mathrm{wk}$ before calving and at the moment of sampling (0-3 DIM) on a 5-point scale divided into quarter-point increments (Edmondson et al., 1989). Ease of calving was assessed according to the following scale from 1 to 3 : unassisted $(1)=$ heifer calved without any assistance; easy pull $(2)=1$ person without mechanical assistance; hard pull $(3)=\geq 2$ persons without mechanical assistance or 1 person with mechanical assistance. This variable was recoded for further analyses (0: no assistance/no difficulties; 1 : assistance required). Udder edema around calving was scored between 0 and 3 DIM: $1=$ no edema, $2=$ slight edema, $3=$ moderate edema, $4=$ severe edema, and $5=$ extremely severe edema (Dentine and McDaniel, 1983). Recoding into a binary variable was applied for further analyses (0: no or slight edema; 1: moderate to extremely severe edema).

Quarter-Level Risk Factors. Several potential quarter-level risk factors were recorded at the moment of sampling (0-3 DIM). The presence/absence of teat-end lesions was recorded based on a visual scoring system (Neijenhuis et al., 2000) and expressed by the thickness of the callosity ring categorized into 5 classes: none $(\mathrm{N})$, slight $(\mathrm{A})$, moderate $(\mathrm{B})$, thick $(\mathrm{C})$, and extreme (D). Additionally, the ring was classified as smooth (1) or rough (2). The scoring system was simplified as proposed by Mein et al. (2001): no ring $(\mathrm{N})$, smooth or slightly rough $=$ a raised ring with no roughness or only mild roughness and no keratin fronds $(1 \mathrm{~A}, 1 \mathrm{~B}, 1 \mathrm{C}$, or $2 \mathrm{~A})$, rough $=$ a raised roughened ring with isolated fronds of old keratin extending 1 to $3 \mathrm{~mm}$ from the orifice $(2 \mathrm{~B}$ or $2 \mathrm{C})$, very rough $=$ a raised ring with rough fronds of old keratin extending $>4 \mathrm{~mm}$ from the orifice. The rim of the ring is rough and cracked, giving the teat-end a "flowered" appearance (2D). None of the teats had a rough or very rough teat end. Scoring of teat skin condition was performed by means of palpation and visual inspection. Teat skin condition was classified as normal (i.e., smooth sheen, soft, healthy skin), dry (i.e., scaly, flaky, or rough skin, but without cracking), damaged (i.e., chapped with cracks), or severely damaged [i.e., deep chaps, scabs, or open (ulcerative) lesions]. The variable was recoded into a binary variable for further analyses (0: normal teat skin condition; 1: dry, damaged, or severely damaged teat skin). None of the teats was severely damaged. 
Table 2. Summary of all potential herd-, heifer-, and quarter-level risk factors

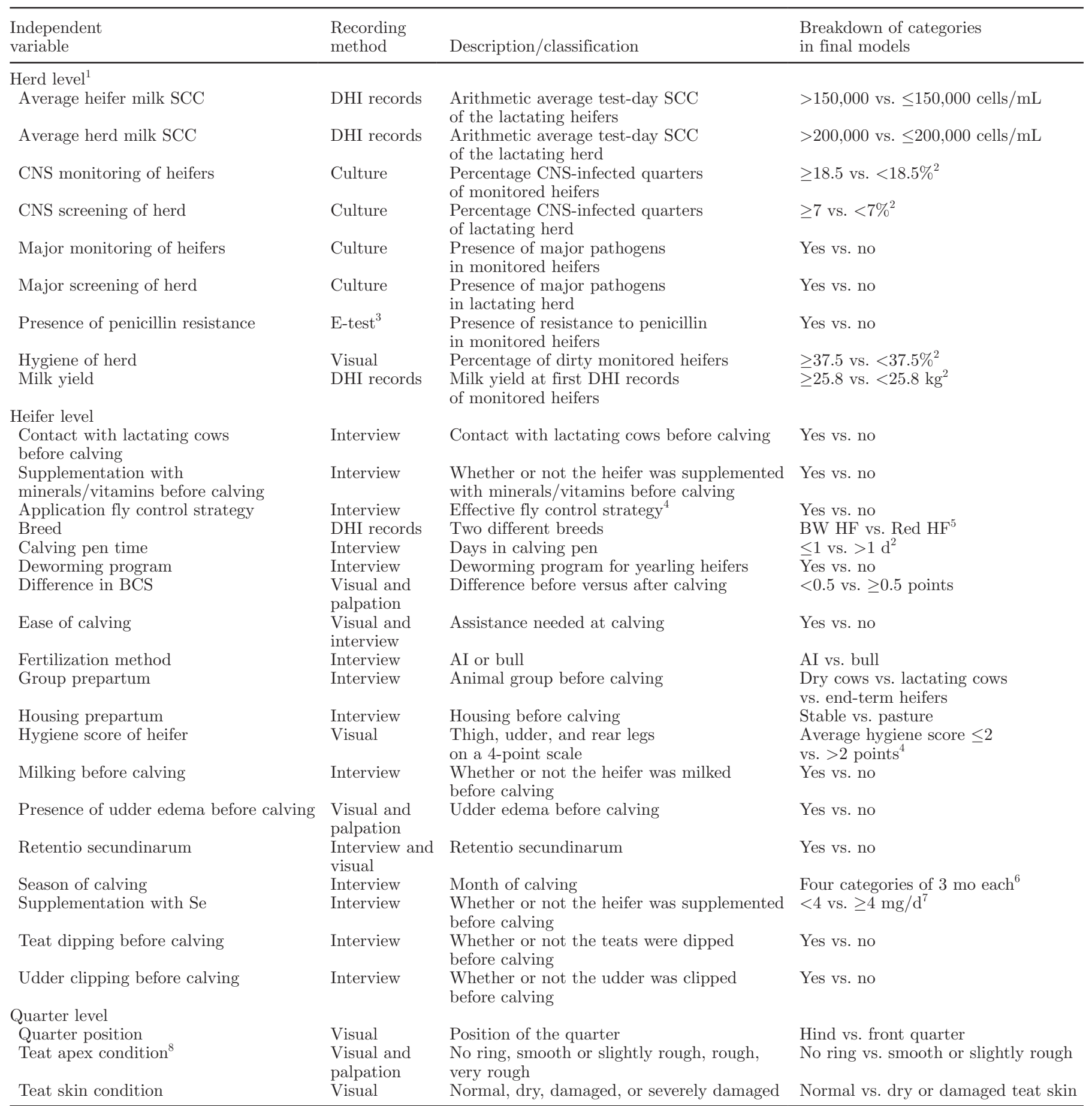

${ }^{1}$ Binomial herd-level predictor variables constructed using data from monitored heifers before the start of the actual clinical trial.

${ }^{2}$ Threshold based on median value of study population.

${ }^{3} \mathrm{AB}$ Biodisk (Solna, Sweden). The E-test is a stable-gradient agar diffusion technique that produces quantitative MIC results over a $15 \log _{2}$ dilution range (Brown and Brown, 1991).

${ }^{4}$ Two Flectron ear tags (Zoetis Inc., Florham Park, NJ) just before having access to pasture or during pasture season treated strictly in accordance with the manufacturer's instructions with a pour-on solution registered for fly control in dairy cattle.

${ }^{5} \mathrm{BW}$ HF $=$ Black and White Holstein-Friesian; Red HF = Red Holstein-Friesian.

${ }^{6}$ January to March, April to June, July to September, and October to December.

${ }^{7} \mathrm{NRC}(2001)$.

${ }^{8}$ The presence/absence of teat-end lesions was recorded based on a visual scoring system (Neijenhuis et al., 2000). Additionally, the ring was classified as smooth (1) or rough (2). The scoring system was simplified as proposed by Mein et al. (2001). 


\section{Definition of IMI}

A quarter was considered to have an IMI in early lactation (0-3 DIM) when the same mastitis pathogen was isolated from both duplicate milk samples (Borm et al., 2006). A quarter was considered as noninfected when no pathogens were isolated from both duplicate milk samples. When a mastitis pathogen was isolated only in one sample from both duplicate milk samples or when one or both milk samples were contaminated, the data were considered missing.

Clinical mastitis was recorded by the first author and was defined as the presence of visual signs, such as clots in the milk, with or without redness, swelling of the udder quarter, or systemic signs.

\section{Statistical Analyses}

Prior to statistical analysis, observations were explored and checked for unlikely values. No data were excluded for this reason. The data set was divided in 2 subsets containing the data from the treated heifers and the data from the untreated control heifers, respectively. All analyses were performed on both subsets of data separately.

Logistic mixed regression models using first-order marginal quasi-likelihood algorithms were fit in MLwiN 2.02.03 software (Centre for Multilevel Modelling, Bristol, UK). Heifer and herd were included as random effects to correct for the clustering of quarters within heifer and heifers within herd. Statistical analyses were conducted with quarter as a unit of analysis.

First, univariable associations between the 2 binary outcome variables (1) IMI with CNS versus noninfected at the quarter level $(0=$ noninfected vs. $1=$ infected with CNS) and (2) IMI with major pathogens versus noninfected at the quarter level $(0=$ noninfected vs. 1 $=$ infected with a major pathogen), and all independent variables at the herd, heifer, and quarter level were tested. Statistical significance in this step was assessed at $P<0.20$. Second, Pearson and Spearman correlation coefficients were calculated among the significant independent variables to check for multicollinearity. If 2 independent variables had a correlation coefficient $\geq 0.6$, only the one with the highest statistical significance was selected for further analysis. None of the variables had to be omitted because of this reason. In the third step, multivariable models were fit with statistical significance set at $P<0.05$. A variable was considered to act as a confounder if its removal made the regression coefficients of the remaining variables undergo a relative change $>25 \%$ or, in the case of the regression coefficient ranging between -0.4 and 0.4 , if an absolute change $>0.1$ was observed (Noordhuizen et al., 2001). Finally, all first-order interactions among the remaining independent variable in the multivariable models were tested and removed when nonsignificant (Wald's test $P$ $>0.05$ ). The fit of the final models was evaluated by the inspection of the quarter-level standardized residuals plotted against the normal scores and against the quarter-level predicted values, and by calculation of the deviance chi-squared statistic to the remaining degrees of freedom (Dohoo et al., 2009). The Hosmer-Lemeshow goodness-of-fit measure and the sensitivity and specificity of the model were assessed on the fixed-effect models only (Dohoo et al., 2009) using SAS (PROC LOGISTIC, version 9.3; SAS Institute Inc., Cary, NC).

The proportion of variation for IMI with CNS and IMI with major pathogens present at the herd, heifer, and quarter levels for both the null and the final models was estimated by assuming that the total variance at the quarter level on the logit scale was $\pi^{2} / 3$, where $\pi=$ 3.1416 (Dohoo et al., 2001). Using this approach, the total variance $\left[\operatorname{Var}\left(Z_{i j k}\right)\right]$ was estimated as follows:

$$
\begin{aligned}
& \operatorname{Var}\left(Z_{i j k}\right)=\operatorname{var}\left(\mu_{\mathrm{Herd}(j)}\right)+\operatorname{var}\left(\mu_{\mathrm{Heifer}(k)}\right)+\operatorname{var}\left(\varepsilon_{i j k}\right) \\
& =\sigma_{\text {Herd }}^{2}+\sigma_{\text {Heifer }}^{2}+\pi^{2} / 3
\end{aligned}
$$

where $\mu_{\operatorname{Herd}(j)}=$ random effect of the herd $i, \mu_{\operatorname{Heifer}(k)}=$ random effect of the heifer $j$ to correct for clustering of the quarters $k$ within heifers, $\varepsilon_{i j k}=$ random error term, $\sigma_{\text {Herd }}^{2}=$ variance occurring at the herd level, $\sigma_{\text {Heifer }}^{2}=$ variance occurring at the heifer level, and $\pi^{2} / 3=$ variance occurring at the quarter level.

\section{RESULTS}

\section{Descriptive Results}

In total, 149 heifers (596 quarters), of which 76 were treated heifers (304 quarters) and 73 were untreated heifers (292 quarters), were included in the trial (Passchyn et al., 2013).

Overall, in early lactation, 347 quarters were noninfected, 34 quarters $(5.7 \%)$ were infected with a major pathogen [14 (2.3\%) in treated heifers and $20(3.4 \%)$ in untreated heifers], and 94 quarters $(15.8 \%)$ with CNS [40 $(6.7 \%)$ in treated heifers and $54(9.1 \%)$ in untreated heifers]. Within the major pathogens, Staph. aureus (n $=6)$, Strep. uberis $(\mathrm{n}=10)$, Strep. dysgalactiae $(\mathrm{n}=$ 3 ), other streptococci $(\mathrm{n}=11)$, and $E$. $\operatorname{coli}(\mathrm{n}=4)$ were isolated. Milk samples from 37 quarters were contaminated and for 84 quarters, assignment of an IMI status was not possible, because in only one sample from both 
duplicate samples could a mastitis pathogen be isolated (data encoded as missing values). In addition, 6 quarters from 6 heifers in the treatment group showed signs of CM in early lactation (4\%). Streptococcus uberis (n $=1)$, C. bovis $(\mathrm{n}=1)$, and Staph. aureus $(\mathrm{n}=1)$ were isolated; 1 sample was contaminated and 2 samples remained culture negative.

\section{Risk Factors for IMI in Untreated Heifers}

Four and 2 risk factors, respectively, were unconditionally associated $(P \leq 0.20)$ with IMI with CNS and IMI with major pathogens in untreated heifers (Tables 3 and 4 ).

The final models revealed that quarters from untreated heifers that were supplemented with Se prepartum
( $\geq 4 \mathrm{mg} / \mathrm{d}$ ) were significantly less likely to be infected with CNS, whereas when assistance during calving was needed, quarters were significantly more likely to be infected with CNS (Table 5). Udder edema before calving significantly decreased the odds of IMI with major pathogens (Table 5).

The model sensitivity (ability to predict occurrence of IMI) was $49.2 \%$ for the model of IMI with CNS and $43.5 \%$ for the model of IMI with major pathogens. The model specificity (ability to predict nonoccurrence of IMI) was 84.1 and $90.9 \%$, respectively. The HosmerLemeshow test for the final model with IMI with CNS was not statistically significant $(P=0.25)$. The deviance chi-squared statistic per degree of freedom was 1.05 for the model based on IMI with CNS and 0.95 for the model based on IMI with major pathogens, indicating a good model fit.

Table 3. Significant $(P \leq 0.20)$ unconditional associations at the herd, heifer, and quarter levels for IMI with CNS in untreated and treated heifers based on logistic mixed regression models (see Table 2 for details on the different independent variables)

\begin{tabular}{|c|c|c|c|c|c|c|}
\hline \multirow[b]{3}{*}{ Independent variable } & \multicolumn{6}{|c|}{ IMI with CNS } \\
\hline & \multicolumn{3}{|c|}{ Untreated heifers } & \multicolumn{3}{|c|}{ Treated heifers } \\
\hline & No. ${ }^{1}$ & $\%^{2}$ & $P$-value & No. ${ }^{1}$ & $\%^{2}$ & $P$-value \\
\hline \multicolumn{7}{|l|}{ Herd level } \\
\hline Average heifer milk SCC & & & 0.20 & & & NS \\
\hline$>150,000$ cells $/ \mathrm{mL}$ & 84 & 19.0 & & - & - & \\
\hline$\leq 150,000$ cells $/ \mathrm{mL}$ & 130 & 29.2 & & - & - & \\
\hline CNS screening of herd & & & NS & & & 0.15 \\
\hline$>18.5 \%$ & - & - & & 94 & 23.4 & \\
\hline$\overline{<} 18.5 \%$ & - & - & & 133 & 13.5 & \\
\hline \multicolumn{7}{|l|}{ Heifer level } \\
\hline Hygiene score of the heifer & & & NS & & & 0.080 \\
\hline Clean & - & - & & 182 & 20.3 & \\
\hline Unclean & - & - & & 45 & 6.7 & \\
\hline Deworming program & & & NS & & & 0.093 \\
\hline Yes & - & - & & 83 & 25.3 & \\
\hline No & - & - & & 144 & 13.2 & \\
\hline Ease of calving & & & 0.005 & & & NS \\
\hline Assistance & 41 & 48.8 & & - & - & \\
\hline No assistance & 173 & 19.6 & & - & - & \\
\hline Group prepartum & & & NS & & & 0.085 \\
\hline Dry cows & - & - & & 129 & 23.2 & \\
\hline Lactating cows & - & - & & 30 & 3.3 & \\
\hline End-term heifers & & & & 68 & 13.2 & \\
\hline Housing prepartum & & & 0.049 & & & NS \\
\hline Stable & 163 & 20.9 & & - & - & \\
\hline Pasture & 51 & 39.2 & & - & - & \\
\hline Season of calving & & & NS & & & 0.064 \\
\hline January-March & - & - & & 71 & 14.1 & \\
\hline April--June & - & - & & 25 & 28.0 & \\
\hline July-September & - & - & & 61 & 24.9 & \\
\hline October-December & - & - & & 70 & 11.4 & \\
\hline Supplementation with Se & & & 0.028 & & & NS \\
\hline$\geq 4 \mathrm{mg} / \mathrm{d}$ & 67 & 13.4 & & - & - & \\
\hline$<4 \mathrm{mg} / \mathrm{d}$ & 147 & 30.6 & & - & - & \\
\hline Quarter level & - & - & - & - & - & - \\
\hline
\end{tabular}


Table 4. Significant $(P \leq 0.20)$ unconditional associations at the herd, heifer, and quarter levels for IMI with major pathogens in untreated and treated heifers based on logistic mixed regression models (see Table 2 for details on the different independent variables)

\begin{tabular}{|c|c|c|c|c|c|c|}
\hline \multirow[b]{3}{*}{ Independent variable } & \multicolumn{6}{|c|}{ IMI with major pathogens } \\
\hline & \multicolumn{3}{|c|}{ Untreated heifers } & \multicolumn{3}{|c|}{ Treated heifers } \\
\hline & No. ${ }^{1}$ & $\%^{2}$ & $P$-value & No. ${ }^{1}$ & $\%^{2}$ & $P$-value \\
\hline \multicolumn{7}{|l|}{ Herd level } \\
\hline Average herd milk SCC & & & NS & & & 0.083 \\
\hline$<200,000$ cells $/ \mathrm{mL}$ & - & - & & 133 & 9.8 & \\
\hline$\geq 200,000$ cells $/ \mathrm{mL}$ & - & - & & 68 & 1.5 & \\
\hline \multicolumn{7}{|l|}{ Heifer level } \\
\hline Calving pen time & & & NS & & & 0.006 \\
\hline$\leq 1 \mathrm{~d}$ & - & - & & 120 & 3.3 & \\
\hline$>1 \mathrm{~d}$ & - & - & & 81 & 12.3 & \\
\hline Contact with lactating cows before calving & & & NS & & & 0.10 \\
\hline Yes & - & - & & 44 & 16.0 & \\
\hline No & - & - & & 155 & 4.5 & \\
\hline Udder edema before calving & & & 0.019 & & & NS \\
\hline Yes & 91 & 4.4 & & - & - & \\
\hline No & 89 & 18.0 & & - & - & \\
\hline Fertilization method & & & 0.029 & & & NS \\
\hline $\mathrm{AI}$ & 154 & 7.8 & & - & - & \\
\hline Bull & 26 & 30.1 & & - & - & \\
\hline Group prepartum & & & NS & & & 0.12 \\
\hline Dry cows & - & - & & 102 & 2.9 & \\
\hline Lactating cows & - & - & & 36 & 19.4 & \\
\hline End-term heifers & - & - & & 63 & 6.3 & \\
\hline Quarter level & - & - & - & - & - & - \\
\hline
\end{tabular}

\section{Risk Factors for IMI in Treated Heifers}

Five and 4 risk factors, respectively, were unconditionally associated $(P \leq 0.20)$ with IMI with CNS and IMI with major pathogens in treated heifers (Tables 3 and 4).

For IMI with CNS, no risk factors were detected (Table 5). In the final model for IMI with major pathogens, 2 risk factors were significant: quarters were significantly more likely to be infected with major pathogens if a heifer was housed in the calving pen for more than $1 \mathrm{~d}$, and if a heifer had been in contact with the lactating cows before calving (Table 5).

For the final model of IMI with major pathogens, the model sensitivity (ability to predict occurrence of IMI) and specificity (ability to predict nonoccurrence of IMI) were 64.5 and $86.8 \%$, respectively. The HosmerLemeshow test was not statistically significant $(P=$ 0.93). The deviance chi-squared statistic per degree of freedom was 0.99 , indicating a good model fit.

\section{Variance Components}

The variance components for the different models are presented in Tables 6 and 7. For the null model of CNS IMI in treated and untreated heifers, 31.1 and 23.9\% of the variation resided at the heifer level, respectively. For IMI with major pathogens in treated and untreated heifers, this was 54.3 and $41.9 \%$, respectively. No variation resided at the herd level in the models with CNS IMI as the outcome, whereas some variation resided at this level in the models with IMI with major pathogens as the outcome variable.

\section{DISCUSSION}

To our knowledge, this is the first study investigating pathogen group-specific risk factors for IMI in both treated and untreated heifers participating in a prepartum antimicrobial treatment trial. Treated and untreated heifers were part of the same management when housed at the same farm, allowing us to compare risk factors in play, besides determining the variance components.

When looking at the unconditional associations as well as at the final models, the risk factors for IMI that were identified in treated heifers were different than those in untreated heifers, independent of the pathogen group that was considered. It looks as if prepartum treatment not only changed the likelihood of infection (Passchyn et al., 2013), but also the factors that were associated with infection. This suggests that in herds 
where prepartum treatment is implemented, prevention should focus on other aspects than in herds where no such programs are in place, although this needs to be substantiated in future research.

As no other studies have reported on risk factors for IMI in heifers that were treated with antimicrobials before calving, we limited ourselves to comparing the factors associated with the IMI likelihood found in the untreated control heifers with those reported in the scientific literature. The fact that moderate to excessive edema before calving was negatively associated with the likelihood of IMI with major pathogens in untreated control heifers was unexpected and was in contrast to previous findings (Slettbakk et al., 1995; Waage et al., 2001; Compton et al., 2007). Actually, we have also reported before that udder edema before calving was positively associated with the likelihood of IMI in heifers, with contagious major pathogens to be more specific, but not with the likelihood of IMI with environmental major pathogens (Piepers et al., 2011). Because of the limited number of IMI with major pathogens $(\mathrm{n}=20)$ in the current study, stratification into environmental and contagious major pathogens was not possible.

Selenium supplementation ( $\geq 4 \mathrm{mg} / \mathrm{d}$ ) was negatively associated with the likelihood of CNS IMI in control heifers, somewhat contrasting with the findings of a previous study (Piepers et al., 2011) in which no association could be found between Se supplementation before calving and the likelihood of CNS IMI. Because CNS is a large group consisting of different species, together with the fact that species seem to behave differently (Supré et al., 2011; Piessens et al., 2012), and because the CNS isolates from the current study were not identified to the species level, we could not further elaborate this finding. Still, it can be anticipated that different species were involved, explaining the contradictions between studies. In any case, it underlines the need to study risk factors for CNS species-specific IMI, but this needs large studies and data sets (e.g., Reyher et al., 2011) larger than the one that is presented in this article.

Observational studies have suggested that dystocia is associated with a higher risk of CM in heifers within a month of calving compared with eutocia (Oltenacu and Ekesbo, 1994; Barnouin and Chassagne, 2001; Svensson et al., 2006). Our study confirms these findings, as quarters belonging to heifers undergoing dystocia were more likely to have CNS IMI than quarters from heifers where no assistance was required during calving. Still, the majority of cases of IMI in our study were not associated with clinical signs, as expected, because CNS are not likely to cause CM (Supré et al., 2011; Hertl et al., 2014), which is a substantial difference. Svensson 
Table 6. Variance components at the herd, heifer, and quarter levels of the null models and the final multivariable models for IMI with CNS in untreated heifers and treated heifers

\begin{tabular}{|c|c|c|c|c|}
\hline \multirow[b]{3}{*}{ Data hierarchy } & \multicolumn{4}{|c|}{ IMI with CNS } \\
\hline & \multicolumn{2}{|c|}{ Untreated heifers } & \multicolumn{2}{|c|}{ Treated heifers } \\
\hline & Var. Est. ${ }^{1} \pm \mathrm{SE}$ & $\%$ & Var. Est. $\pm \mathrm{SE}$ & $\%$ \\
\hline \multicolumn{5}{|l|}{ Null model } \\
\hline Herd & 0 & 0 & 0 & 0 \\
\hline Heifer & $1.036 \pm 0.467$ & 23.9 & $1.486 \pm 0.614$ & 31.1 \\
\hline Quarter & $3.289^{2}$ & 76.1 & $3.289^{2}$ & 68.9 \\
\hline Total variance & 4.387 & 100.0 & 4.776 & 100.0 \\
\hline \multicolumn{5}{|c|}{ Final multivariable model } \\
\hline Herd & 0 & 0 & 0 & 0 \\
\hline Heifer & $0.722 \pm 0.437$ & 18.0 & $1.486 \pm 0.614$ & 31.1 \\
\hline Quarter & $3.289^{2}$ & 82.0 & $3.289^{2}$ & 68.9 \\
\hline Total variance & 4.308 & 100.0 & 4.776 & 100.0 \\
\hline
\end{tabular}

${ }^{1}$ Var. Est. = variance estimate.

${ }^{2} \pi^{2} / 3=$ variance occurring at the quarter level (Dohoo et al., 2001).

et al. (2006) hypothesized that the association between reproductive disorders and $\mathrm{CM}$ could be due to a common factor affecting both disease complexes. Based on the conclusions of Proudfoot et al. (2009), who showed that cows with dystocia had reduced DMI and water intake $24 \mathrm{~h}$ before calving, a more pronounced negative energy balance in heifers that needed assistance and decreased weakened immunity could possibly explain this finding. Still, it does not explain why this factor was not associated with IMI with major pathogens.

Quarters from treated heifers staying in the calving pen for more than $1 \mathrm{~d}$ were more likely to be infected with major pathogens. As almost $50 \%$ of the farms in Flanders use their calving pens for both sick and periparturient cows (De Vliegher et al., 2004), we hypothesize that a prolonged stay in a more infectious environment explains this finding. In our study as well, 8 out of 10 farmers used their calving pen for both sick and periparturient cows.

Except in the model for IMI with major pathogens in treated heifers, all variation in the likelihood of IMI with both CNS and major pathogens occurred at the heifer and quarter level and none at the herd level. This coincides with our previous findings studying earlylactation SCC in heifers (De Vliegher et al., 2004). Approximately $97 \%$ of the variance in that outcome variable occurred at the heifer level, with very small variance estimates at the herd level. At that time, we suggested that focusing on heifers rather than on the herds seems to be necessary when dealing with heifer mastitis in the short term, and this also seems to be the case when studying IMI. However, as the variation

Table 7. Variance components at the herd, heifer, and quarter levels of the null models and the final multivariable models for IMI with major pathogens in untreated heifers and treated heifers

\begin{tabular}{|c|c|c|c|c|}
\hline \multirow[b]{3}{*}{ Data hierarchy } & \multicolumn{4}{|c|}{ IMI with major pathogens } \\
\hline & \multicolumn{2}{|c|}{ Untreated heifers } & \multicolumn{2}{|c|}{ Treated heifers } \\
\hline & Var. Est. ${ }^{1} \pm \mathrm{SE}$ & $\%$ & Var. Est. $\pm \mathrm{SE}$ & $\%$ \\
\hline \multicolumn{5}{|l|}{ Null model } \\
\hline Herd & 0 & 0 & $0.245 \pm 0.776$ & 3.2 \\
\hline Heifer & $2.369 \pm 1.049$ & 41.9 & $4.201 \pm 1.762$ & 54.3 \\
\hline Quarter & $3.289^{2}$ & 58.1 & $3.289^{2}$ & 42.5 \\
\hline Total variance & 5.761 & 100.0 & 7.736 & 100.0 \\
\hline \multicolumn{5}{|c|}{ Final multivariable model } \\
\hline Herd & $0.211 \pm 0.545$ & 4.0 & $1.671 \pm 1.216$ & 30.4 \\
\hline Heifer & $1.719 \pm 1.050$ & 33.0 & $0.537 \pm 0.914$ & 9.8 \\
\hline Quarter & $3.289^{2}$ & 63.0 & $3.289^{2}$ & 59.8 \\
\hline Total variance & 5.216 & 100.0 & 5.498 & 100.0 \\
\hline
\end{tabular}

${ }^{1}$ Var. Est. = variance estimate.

${ }^{2} \pi^{2} / 3$ = variance occurring at the quarter level (Dohoo et al., 2001). 
residing at the herd level for IMI with major pathogens was higher in the treated heifers compared with the untreated heifers, we speculate that some herds benefit more from treatment than others. It is indeed well established that treatment of mastitis is more effective in well-managed than in poorly managed herds where cured cows or heifers are more likely to become reinfected (Barlow et al., 2009).

The heifer-level variation for both IMI with CNS and IMI with major pathogens was more pronounced in treated heifers than in untreated heifers. Although we considered 2 different data sets, making comparison difficult or even unwanted, we hypothesize that some heifers benefit more from treatment than others, especially heifers with an IMI with major pathogens. This hypothesis is supported by 2 other studies in which both the average cure rate (Borm et al., 2006) and the number of infected quarters (Sampimon et al., 2009; Passchyn et al., 2013) of prepartum treated heifers differed between both herds and heifers within herds. Still, the lack of data on cure rates in our study makes it difficult to further substantiate this hypothesis.

The fact that most of the variation in IMI with CNS resided at the quarter level and in IMI with major pathogens at the heifer level can probably be explained by the fact that quarters are more likely to be infected with CNS than with a major pathogen. In the current study, $15.8 \%$ of the quarters were infected with CNS and $5.7 \%$ with a major pathogen, prevalences that are in line with those from the literature (Fox, 2009; De Vliegher et al., 2012). The fact that when cows have an IMI with CNS, often more than 1 quarter per cow is infected with CNS has been described before (Piepers et al., 2007).

Except for treated heifers with an IMI with major pathogens, only a small proportion of the variation in the outcome variables was explained in the final multivariable models. This indicates that factors other than those we studied could explain the likelihood of infection (e.g., anatomy of the teat, genetic background of heifer, or young stock management). The same finding by De Vliegher et al. (2004) actually urged us to study the genetic background of heifer mastitis and, by focusing on the $C X C R 1$ gene, we recently described susceptibility in heifers that was different for CNS compared with major pathogens (Verbeke et al., 2012). In treated heifers, avoiding contact with lactating cows before calving and keeping the fresh heifers in the calving pen only for a short period of time $(<1 \mathrm{~d})$ seem to be important measures to reduce the (re)infection risk. In general and at the same time, additional unstudied risk factors at the herd level must be further explored (e.g., barn design and feeding, among others).

\section{CONCLUSIONS}

Quarters from untreated heifers supplemented with $\geq 4 \mathrm{mg} \mathrm{Se} / \mathrm{d}$ prepartum were significantly less likely to be infected with CNS, whereas quarters were more likely to be infected with CNS when assistance during calving was needed. Udder edema before calving was negatively associated with the likelihood of IMI with major pathogens. In treated heifers, no factors were detected that were associated with the likelihood of CNS IMI, whereas quarters from heifers were significantly more likely to be infected with major pathogens when the heifers were housed in the calving pen more than 1 $\mathrm{d}$, and when they had been in contact with the lactating cows before calving. Strikingly, all identified risk factors for IMI in treated heifers, also in the univariable analyses, were different than those in untreated heifers, indicating that prepartum systemic antimicrobial treatment does not only change the likelihood of infection but also the factors that are associated with infection. Factors other than those we studied could explain the likelihood of infection, as only a small proportion of the variation was explained in the final models, except for the one describing the likelihood of major pathogen IMI in treated heifers. More and different risk factors at the quarter (e.g., anatomy of the teat), heifer (e.g., genetics and immunity), and herd level (e.g., barn design and nutrition) should be included in future research.

\section{ACKNOWLEDGMENTS}

The treatment trial referred to in this study was funded by Boehringer Ingelheim Animal Health (Ingelheim, Germany). The authors thank the herd managers for participating in the study and for their assistance. Milk Control Center Flanders (Lier, Belgium) is acknowledged for performing all laboratory analyses.

\section{REFERENCES}

Barlow, J. W., L. J. White, R. N. Zadoks, and Y. H. Schukken. 2009. A mathematical model demonstrating indirect and overall effects of lactation therapy targeting subclinical mastitis in dairy herds. Prev. Vet. Med. 90:31-42.

Barnouin, J., and M. Chassagne. 2001. Predictive variables for the occurrence of early clinical mastitis in primiparous Holstein cows under field conditions in France. Can. Vet. J. 42:47-53.

Borm, A. A., L. K. Fox, K. E. Leslie, J. S. Hogan, S. M. Andrew, S. P. Oliver, Y. H. Schukken, D. D. Hancock, C. T. Gaskins, W. E. Owens, and C. Norman. 2006. Effects of prepartum intramammary antibiotic therapy on udder health, milk production, and reproductive performance in dairy heifers. J. Dairy Sci. 89:2090-2098.

Brown, D. F. J., and L. Brown. 1991. Evaluation of the E test: A novel method of quantifying antimicrobial activity. J. Antimicrob. Chemother. 27:185-190.

Compton, C. W. R., C. Heuer, K. Parker, and S. McDougall. 2007. Epidemiology of mastitis in pasture-grazed peripartum dairy heifers and its effects on productivity. J. Dairy Sci. 90:4157-4170. 
De Vliegher, S., H. W. Barkema, G. Opsomer, A. de Kruif, and L. Duchateau. 2005a. Association between somatic cell count in early lactation and culling of dairy heifers using Cox frailty models. J. Dairy Sci. 88:560-568.

De Vliegher, S., H. W. Barkema, H. Stryhn, G. Opsomer, and A. de Kruif. 2004. Impact in dairy heifers of early lactation somatic cell count on somatic cell counts during the first lactation. J. Dairy Sci. 87:3672-3682.

De Vliegher, S., H. W. Barkema, H. Stryhn, G. Opsomer, and A. de Kruif. 2005b. Impact of early lactation somatic cell count in heifers on milk yield over the first lactation. J. Dairy Sci. 88:938-947.

De Vliegher, S., L. K. Fox, S. Piepers, S. McDougall, and H. W. Barkema. 2012. Invited review: Mastitis in dairy heifers: Nature of the disease, potential impact, prevention, and control. J. Dairy Sci. 95:1025-1040.

Dentine, M. R., and B. T. McDaniel. 1983. Variation in edema scores from herd-year, age, calving month and sire. J. Dairy Sci. $66: 2391-2399$.

Dohoo, I. R., S. W. Martin, and H. Stryhn. 2009. Mixed models for discrete data. Pages 584-585 in Veterinary Epidemiologic Research. Vol. 2. I. R. Dohoo, W. Martin, and H. Stryhn, ed. VER Inc., Charlottetown, PE, Canada.

Dohoo, I. R., E. Tillard, H. Stryhn, and B. Faye. 2001. The use of multilevel models to evaluate sources of variation in reproductive performance in dairy cattle in Reunion Island. Prev. Vet. Med. 50:127-144.

Edmondson, A. J., I. L. Lean, L. D. Weaver, T. Farver, and G. Webster. 1989. A body condition scoring chart for Holstein dairy cows. J. Dairy Sci. 72:68-78.

EUCAST (European Committee on Antimicrobial Susceptibility Testing). 2011. Clinical Breakpoint Table. Accessed June 1, 2012. http://www.eucast.org/antimicrobial_susceptibility_testing/prev ious_versions_of_tables/.

Fox, L. K. 2009. Prevalence, incidence and risk factors of heifer mastitis. Vet. Microbiol. 134:82-88.

Hertl, J. A., Y. H. Schukken, F. L. Welcome, L. W. Tauer, and Y. T. Gröhn. 2014. Pathogen-specific effects on milk yield in repeated clinical mastitis episodes in Holstein dairy cows. J. Dairy Sci. 97:1465-1480.

Hughes, J. 2001. A system for assessing cow cleanliness. In Pract. $23: 517-524$.

McDougall, S., K. I. Parker, C. Heuer, and C. W. R. Compton. 2009. A review of prevention and control of heifer mastitis via non-antibiotic strategies. Vet. Microbiol. 134:177-185.

Mein, G. A., F. Neijenhuis, W. F. Morgan, D. J. Reinemann, J. E. Hillerton, J. R. Baines, and I. Ohnstad, M. D. Rasmussen, L. Timms, J. S. Britt, R. Farnsworth, N. B. Cook, and T. Hemling. 2001. Evaluation of bovine teat condition in commercial dairy herds: 1. Non-infectious factors. Pages 347-351 in Proc. 2nd Int. Symp. on Mastitis and Milk Quality, Vancouver, Canada. Natl. Mastitis Counc., Madison WI; Am. Assoc. Bovine Pract., Rome, GA.

Neijenhuis, F., H. W. Barkema, H. Hogeveen, and J. P. T. M. Noordhuizen. 2000. Classification and longitudinal examination of callused teat ends in dairy cows. J. Dairy Sci. 83:2795-2804.

Nickerson, S. C. 2009. Control of heifer mastitis: Antimicrobial treatment-An overview. Vet. Microbiol. 134:128-135.

Noordhuizen, J. P. T. M., K. Frankena, M. V. Thrusfield, and E. A. M. Graat. 2001. Application of quantitative methods in veterinary epidemiology. Wageningen Press, Wageningen, the Netherlands.

NRC. 2001. Nutrient Requirements of Dairy Cattle. 7th rev. ed. National Academy Press, Washington, DC.

Oltenacu, P. A., and I. Ekesbo. 1994. Epidemiological study of clinical mastitis in dairy cattle. Vet. Res. 25:208-212.

Passchyn, P., S. Piepers, and S. De Vliegher. 2013. Systemic prepartum treatment of end-term dairy heifers with penethamate hydriodide: Effect on udder health, milk yield and culling until 120 days in milk. J. Dairy Sci. 96:6324-6335.
Pearson, L. J., J. H. Williamson, S. A. Turner, S. J. Lacy-Hulbert, and J. E. Hillerton. 2013. Peripartum infection with Streptococcus uberis but not coagulase-negative staphylococci reduced milk production in primiparous cows. J. Dairy Sci. 96:158-164.

Piepers, S., L. De Meulemeester, A. de Kruif, G. Opsomer, H. W. Barkema, and S. De Vliegher. 2007. Prevalence and distribution of mastitis pathogens in subclinically infected dairy cows in Flanders, Belgium. J. Dairy Res. 74:478-483.

Piepers, S., S. De Vliegher, A. de Kruif, G. Opsomer, and H. W Barkema. 2009. Impact of intramammary infections in dairy heifers on future udder health, milk production, and culling. Vet. Microbiol. 134:113-120.

Piepers, S., G. Opsomer, H. W. Barkema, A. de Kruif, and S. De Vliegher. 2010. Heifers infected with coagulase-negative staphylococci in early lactation have fewer cases of clinical mastitis and higher milk production in their first lactation than non-infected heifers. J. Dairy Sci. 93:2014-2024.

Piepers, S., K. Peeters, G. Opsomer, H. W. Barkema, K. Frankena and S. De Vliegher. 2011. Pathogen group specific risk factors at herd, heifer and quarter levels for intramammary infections in early lactating dairy heifers. Prev. Vet. Med. 99:91-101.

Piepers, S., Y. H. Schukken, P. Passchyn, and S. De Vliegher. 2013. The impact of intramammary infection with coagulase-negative staphylococci in early lactating heifers on milk yield throughout first lactation revisited. J. Dairy Sci. 96:5095-5105.

Piessens, V., S. De Vliegher, B. Verbist, G. Braem, A. Van Nuffel, L. De Vuyst, and E. Van Coillie. 2012. Intra-species diversity and epidemiology varies among coagulase-negative Staphylococcus species causing bovine intramammary infections. Vet. Microbiol. 155:62-71.

Proudfoot, K. L., J. M. Huzzey, and M. A. G. von Keyserlingk. 2009. The effect of dystocia on the dry matter intake and behavior of Holstein cows. J. Dairy Sci. 92:4937-4944.

Reyher, K. K., S. Dufour, H. W. Barkema, L. Des Côteaux, T. J. Devries, I. R. Dohoo, G. P. Keefe, J.-P. Roy, and D. T. Scholl. 2011. The National Cohort of Dairy Farms - A data collection platform for mastitis research in Canada. J. Dairy Sci. 94:16161626.

Sampimon, O. C., S. De Vliegher, H. W. Barkema, J. Sol, and T. J. G. M. Lam. 2009. Effect of prepartum dry cow antibiotic treatment in dairy heifers on udder health and milk production. J. Dairy Sci. 92:4395-4403

Schreiner, D. A., and P. Ruegg. 2003. Relationship between udder and leg hygiene scores and subclinical mastitis. J. Dairy Sci. 86:34603465 .

Slettbakk, T., A. Jørstad, T. B. Farver, and J. C. Holmes. 1995. Impact of milking characteristics and morphology of udder and teats on clinical mastitis in first- and second-lactation Norwegian cattle. Prev. Vet. Med. 24:235-244.

Supré, K., F. Haesebrouck, R. N. Zadoks, M. Vaneechoutte, S. Piepers, and S. De Vliegher. 2011. Some coagulase-negative Staphylococcus species affect udder health more than others. J. Dairy Sci. 94:2329-2340.

Svensson, C., A.-K. Nyman, K. Persson-Waller, and U. Emanuelson. 2006. Effects of housing, management, and health of dairy heifers on first-lactation udder health in southwest Sweden. J. Dairy Sci. 89:1990-1999.

Verbeke, J., S. Piepers, L. Peelman, M. Van Poucke, and S. De Vliegher. 2012. Pathogen-group specific association between CXCR1 polymorphisms and subclinical mastitis in dairy heifers. J. Dairy Res. 79:341-351.

Waage, S., S. A. Ødegaard, A. Lund, S. Brattgjerd, and T. Røthe. 2001. Case control study for risk factors for clinical mastitis in postpartum dairy heifers. J. Dairy Sci. 84:392-399. 